\title{
JENIS PANGAN SARAPAN DAN PERANNYA DALAM ASUPAN GIZI HARIAN ANAK USIA 6-12 TAHUN DI INDONESIA
}

\author{
(Type of food for breakfast and its roles in daily nutrient intakes of school age children \\ 6-12 years in Indonesia)
}

Hardinsyah ${ }^{1 *}$ dan Muhammad Aries ${ }^{1}$

'Departemen Gizi Masyarakat FEMA-IPB,

\begin{abstract}
The objective of this study was to analyze the type and amount of food consumed at breakfast and its also contribution in daily nutrient intake of school children (6-12 years old). The data used for this study was the secondary data of the Basic Health Survey 2010 (Riskesdas 2010) conducted by the Research and Development Agency, Ministry of Health. The data of 24-hour recall of food consumption and socio-economic were obtained from 35000 school age children. The results of the study shows that ten most populer food consumed during breakfast are rice, scramble egg, fried tempeh, vegetable soup, fried fish, instant noodle, fried rice, stir vegetable, and fried tofu; and the five most populer beverages consumed during breakfast are drinking water, sweetened tea, milk creamer, powder milk, and tea. Nearly half (44.6\%) of the children breakfast with low nutritional quality. Approximately $44.6 \%, 35.4 \%, 67.8 \%, 85.0 \%, 89.4 \%$, and $90.3 \%$ of children consume only $<15 \%$ RDI for energy, protein, vitamin A, iron, calcium, and fiber respectively. Based on these results and inline with one of the dietary guidelines messages - do breakfast everyday - the healthy breakfast for school children need further promoted intensively. It is suggested that the healthy breakfast should be able to fulfill 15-30\% of daily nutrients requirements.
\end{abstract}

Key words: breakfast, RISKESDAS 2010, school children

\begin{abstract}
ABSTRAK
Tujuan penelitian ini adalah untuk menganalisis jumlah dan jenis makanan dan minuman sarapan serta kontribusinya dalam asupan gizi harian anak usia sekolah (6-12 tahun). Data yang digunakan untuk penelitian ini adalah data sekunder (data konsumsi pangan) yang diperoleh dari hasil penelitian Riset Kesehatan Dasar (Riskesdas) 2010 yang dilaksanakan oleh Badan Penelitian dan Pengembangan Kesehatan Kementerian Kesehatan Indonesia. Data konsumsi pangan (recall 24 jam) dan sosial ekonomi diperoleh dari 35000 subjek anak usia sekolah (6-12 tahun). Hasil penelitian ini menunjukkan bahwa sepuluh makanan yang paling favorit dikonsumsi saat sarapan adalah nasi putih, telur ceplok/dadar, tempe goreng, sayur berkuah, ikan goreng, mi instan, nasi goreng, sayuran (tumis), dan tahu goreng; sedangkan lima minuman terpopuler yang dikonsumsi sebagai sarapan adalah air putih, teh manis, susu kental manis, susu instan, dan air teh. Hampir separuh (44.6\%) anak usia sekolah sarapan dengan kualitas gizi rendah. Sekitar 44.6\%, 35.4\%, 67.8\%, 85.0\%, 89.4\%, dan 90.3\% anak hanya memperoleh gizi <15\% AKG dari sarapan (berturut-turut untuk energi, protein, vitamin A, zat besi, kalsium, dan serat). Berdasarkan hasil tersebut dan juga sejalan dengan salah satu isi Pesan Dasar Umum Gizi Seimbang (PUGS), yaitu "Sarapan setiap hari", maka promosi mengenai kebiasaan sarapan sehat bagi anak usia sekolah perlu dilakukan lebih intensif dan berkelanjutan. Selain itu disarankan pula bahwa sarapan yang sehat sebaiknya mampu memenuhi sekitar 15-30\% AKG.
\end{abstract}

Kata kunci: anak usia sekolah, RISKESDAS 2010, sarapan

"Korespondensi: Departemen Gizi Masyarakat, FEMA, IPB, Bogor, Jl. Lingkar Akademik, Kampus IPB Darmaga, Bogor, 16680. Email: hardinsyah2010@gmail.com 


\section{PENDAHULUAN}

Sarapan penting bagi setiap orang untuk mengawali aktivitas sepanjang hari. Sarapan bertujuan untuk memenuhi kebutuhan zat gizi di pagi hari, sebagai bagian dari pemenuhan gizi seimbang; dan bermanfaat dalam membantu mencegah hipoglikemia, menstabilkan kadar glukosa darah, dan mencegah dehidrasi setelah berpuasa sepanjang malam (Gibson \& Gunn 2011; Hardinsyah 2012). Sarapan atau makan dan minum pagi adalah kegiatan makan dan minum yang dilakukan antara bangun pagi sampai jam 9 untuk memenuhi sebagian (15-30\%) kebutuhan gizi harian dalam rangka mewujudkan hidup sehat, aktif, dan cerdas (Hardinsyah 2012).

Berbagai kajian membuktikan bahwa gizi yang cukup dari sarapan membekali tubuh untuk berpikir, beraktivitas fisik secara optimal setelah bangun pagi. Bagi anak sekolah, sarapan terbukti dapat meningkatkan kemampuan belajar dan stamina anak (Gibson \& Gunn 2011). Dalam jangka panjang, sarapan bermanfaat untuk mencegah kegemukan yang kejadiannya semakin meningkat di Indonesia karena kebiasaan sarapan menanamkan pola makan yang baik. Hal ini dipertegas dengan hasil penelitian Kral et al. (2011) yang menunjukkan bahwa anakanak yang terbiasa sarapan tidak akan makan berlebih di waktu makan berikutnya pada hari tertentu mereka tidak sarapan. Selain itu dengan kebiasaan sarapan juga dapat membantu pengaturan berat badan bagi para penderita obesitas, yaitu dengan cara mengurangi asupan energi dari sarapan dan tetap makan secara teratur dengan asupan energi dan zat gizi yang normal (Schusdziarra et al. 2011; Morales et al. 2011). Penelitian longitudinal selama 20 tahun pada anak di Australia menunjukkan kebiasaan tidak sarapan berisiko meningkatkan lingkar pinggang, kadar total kolesterol darah, dan kadar kolesterol jahat atau LDL (Smith et al. 2010). Asupan gizi dan aktivitas yang tidak seimbang dan aktivitas yang berlebihan dapat menyebabkan gangguan pertumbuhan fisik, ketahanan fisik dan kemampuan belajar anak sekolah. Simon dan Grantham-McGregor (1989) membuktikan bahwa bahwa anak-anak usia 9-11 tahun dengan status gizi kurang yang tidak sarapan, memiliki kemampuan kognitif yang rendah dibanding kontrol.

Sejak pertengahan dekade 1990-an, Kementerian Kesehatan RI sudah memperhatikan pentingnya sarapan melalui promosi kebiasaan sarapan atau makan pagi melalui pesan ke-8 dari 13 pesan umum gizi seimbang, yaitu "Biasakanlah Makan Pagi". Perhatian Pemerintah dalam mengatasi anak yang tidak atau jarang sarapan di perdesaan terutama desa tertinggal diwujudkan melalui pelaksanaan INPRES Nomor 1 Tahun 1997 tanggal 15 Januari 1997 tentang Pemberian Makanan Tambahan bagi Anak Sekolah (PMT-AS) yang berlangsung secara nasional dalam kurun waktu 1997 sampai 2002. Selanjutnya, dalam rangka implementasi kebijakan percepatan pencapaian prioritas pembangunan nasional, pada tahun 2010 ini telah menetapkan INPRES Nomor 1 tahun 2010 tanggal 19 Februari 2010, yang salah satunya mengamanatkan PMT-AS (Penyediaan Makanan Tambahan Anak Sekolah) kepada peserta didik TK/ SD dan RA/MI, terutama di daerah tertinggal, terisolir, terpencil, perbatasan, di pulau-pulau kecil, dan terluar serta di daerah pedalaman. Sayangnya kebijakan PMT-AS ini mengalami pasang surut.

Data tentang masalah sarapan yang ada selama ini di Indonesia didasarkan pada data skala kecil, yaitu data hasil survei Harian Kompas pada tahun 2011 dan belum pernah ada data berskala nasional yang mengungkap tentang masalah jenis dan jumlah makanan dan minuman yang dikonsumsi saat sarapan, mutu gizi sarapan, dan peranannya terhadap kebutuhan gizi harian anak sekolah. Tujuan penelitian ini adalah untuk menganalisis makanan dan minuman sarapan serta kontribusinya dalam asupan gizi harian anak usia sekolah (6-12 tahun).

\section{METODE}

\section{Data, Desain, Waktu, dan Tempat}

Data yang digunakan untuk penelitian ini adalah data sekunder berupa elektronic file yang diperoleh dari hasil penelitian Riset Kesehatan dasar (Riskesdas) 2010 yang dilaksanakan oleh Badan Penelitian dan Pengembangan Kesehatan Kementerian Kesehatan Indonesia. Riskesdas 2010 menggunakan desain cross sectional. Riskesdas 2010 dilakukan pada bulan Mei-Agustus 2010. Pengolahan, analisis dan interpretasi data untuk penelitian ini dilakukan pada awal tahun 2012 di Kampus IPB Darmaga Bogor, Jawa Barat.

\section{Jumlah dan Cara Pengambilan Subjek}

Penelitian ini menggunakan subjek Riskesdas 2010 yang berasal dari 441 kabupaten/kota yang tersebar di 33 provinsi. Populasi dalam Riskesdas 2010 adalah seluruh rumah tangga. Subjek rumah tangga dalam Riskesdas 2010 dipilih berdasarkan listing Sensus Penduduk tahun 2010. Proses pemilihan rumah tangga dilakukan oleh Badan Pusat Statistik (BPS) dengan two stages sampling. Riskesdas mengambil sejumlah blok sensus dari setiap kabupaten/kota yang termasuk ke dalam kerangka sampel kabupaten/kota. Pemilihan blok sensus tersebut dilakukan sepenuhnya oleh BPS dengan memperhatikan status ekonomi, dan rasio perkotaan/pedesaan. Blok sensus tersebut proporsional terhadap jumlah rumah tangga di kabupaten/kota tersebut. Blok sensus yang dipilih untuk kesehatan masyarakat adalah sebesar 2800 blok sensus dengan 70000 rumah tangga. 
Semua subjek tersebut berasal dari 2798 blok sensus dari 441 kabupaten/kota. Jumlah rumah tangga dari blok sensus tersebut sebanyak 69300 rumah tangga dengan jumlah anggota rumah tangga sebanyak 251388 anggota. Dari jumlah subjek tersebut terdapat 36430 anak usia sekolah (6-12 tahun).

\section{Jenis dan Cara Pengumpulan Data}

Data yang digunakan dalam penelitian ini seluruhnya merupakan data sekunder dari Riskesdas 2010 dalam bentuk electronic file berupa entry data dan hasil pengolahan Riskesdas 2010 termasuk data konsumsi zat gizi yang telah dihitung tim Riskedas 2010 berdasarkan Nutrisurvey. Data yang digunakan pada penelitian ini meliputi data identitas subjek (usia, jenis kelamin, berat badan, tinggi badan), status ekonomi tumah tangga (kuintil), jenis dan jumlah pangan, waktu makan, asupan energi protein, vitamin A, besi, kalsium, dan serat (Tabel 1).

\section{Pengolahan dan Analisis Data}

Data yang diperoleh diolah dengan menggunakan program komputer Microsoft Office Excel 2007 dan SPSS 16.0 for windows. Proses pengolahan data meliputi editing dan cleaning. Proses cleaning data dilakukan untuk memastikan bahwa data yang digunakan logis dan sesuai dengan variabel yang ditentukan. Proses cleaning data dilakukan pada data umur, berat badan, tinggi badan, konsumsi pangan, dan tingkat kecukupan gizi.

Subjek dikeluarkan (screened out) bila data tentang umur, berat badan, tinggi badan tidak tersedia. Selain itu subjek juga dikeluarkan jika tidak mengonsumsi air/minuman dan juga bila kondisi konsumsi yang tidak biasa yaitu sedang diet, sakit, puasa atau dalam acara hajatan/hari raya. Subjek juga dikeluarkan bila asupan energinya $<0.3$ atau $>3$ kali lipat dari energi basal dan memiliki tingkat kecukupan gizi $>400 \%$. Berdasarkan proses cleaning maka diperoleh jumlah subjek untuk penelitian ini adalah 35481 anak umur 6-12 tahun.
Penentuan jenis makanan dan minuman sarapan yang favorit didasarkan pada sepuluh peringkat pertama jenis makanan dan lima peringkat pertama jenis minuman yang dikonsumsi oleh seluruh subjek (tingkat partisipasi).

Kebutuhan zat gizi (energi, protein, vitamin A, zat besi, kalsium, dan serat) ditetapkan berdasarkan kebutuhan gizi menurut kelompok umur dalam anjuran kecukupan gizi (AKG) 2004. Khusus untuk kecukupan energi dan protein dilakukan koreksi berat badan.

\section{HASIL DAN PEMBAHASAN}

\section{Jenis dan Jumlah Pangan Sarapan}

Berdasarkan analisis yang telah dilakukan, diketahui bahwa sepuluh jenis makanan yang paling populer sebagai sarapan anak 6-12 tahun adalah nasi putih, telur ceplok/dadar, tempe goreng, sayur berkuah, ikan goreng, mi instan, nasi goreng, sayuran (tumis), tahu goreng, serta roti dan turunannya. Nasi putih merupakan makanan yang paling banyak populer (paling tinggi tingkat partisipasi konsumsinya) saat sarapan. Sebanyak $28.5 \%$ anak usia sekolah (6-12 tahun) mengonsumsi nasi putih sebagai pangan sarapan mereka. Seperti yang telah banyak diketahui bahwa nasi merupakan pangan pokok masyarakat Indonesia, oleh karena itu hal tersebut menjadi sangat wajar dan untuk sarapan, masyarakat pada umumnya mengonsumsi nasi putih dengan lauk yang mudah disiapkan seperti telur ayam yang diceplok, tempe goreng, tahu goreng, dan lainnya. Rata-rata jumlah nasi yang dikonsumsi saat sarapan oleh anak sebanyak $149.19 \mathrm{~g}$ (satu piring dalam satuan rumah tangga/URT) atau jika dikonversi dalam bentuk kalori maka nilainya yaitu 266 kkal.

Lima jenis minuman yang paling populer sebagai sarapan anak 6-12 tahun adalah air putih, teh manis, susu kental manis, susu instan, dan air teh dengan minuman terbanyak dikonsumsi adalah air putih. Jumlah anak yang mengonsumsi air putih saat

Tabel 1. Sumber dan Cara Pengumpulan Data

\begin{tabular}{|c|c|c|}
\hline Peubah & Sumber data yang digunakan & Cara pengumpulan data (Riskesdas 2010) \\
\hline Karakteristik individu & Kuesioner Riskesdas (RKD10.RT) & Wawancara \\
\hline 1. Usia & Blok IV No 7 & \\
\hline 2. Jenis kelamin & Blok IV No 4 & \\
\hline 3. Status ekonomi (kuintil) & Hasil olahan data Riskesdas 2010 & Olahan BPS \\
\hline 4. Antropometri & Kuesioner Riskesdas (RKD10.IND) & Pengukuran langsung \\
\hline a. Berat badan & Blok X No $1 \mathrm{a}, 1 \mathrm{~b}$ & $\begin{array}{l}\text { a. Diukur dengan timbangan berat badan digital } \\
\text { (kapasitas } 150 \mathrm{~kg} \text { dan ketelitian } 50 \mathrm{~g} \text { ) }\end{array}$ \\
\hline b. Tinggi badan & Blok X No 2a, 2b & $\begin{array}{l}\text { b. Diukur dengan alat ukur tinggi badan multi fungsi } \\
\text { (kapasitas ukur } 2 \mathrm{~m} \text { dan ketelitian } 0.1 \text { ) }\end{array}$ \\
\hline 5. Konsumsi pangan dan gizi & Kuesioner Riskesdas (RKD10.IND) & Food recall $1 \times 24$ jam \\
\hline a. Jumlah pangan & Blok IX & Dihitung dengan Nutrisurvey Software \\
\hline b. Jenis pangan & Blok IX & \\
\hline c. Waktu makan (sarapan) & Blok IX & \\
\hline $\begin{array}{l}\text { d. Asupan gizi ( } E, P \text {, vit } A, C a \text {, } \\
\text { Fe, dan serat) }\end{array}$ & Hasil olahan data Riskesdas 2010 & \\
\hline
\end{tabular}


sarapan sebanyak $71.3 \%$ dan rata-rata jumlah yang dikonsumsi adalah sebanyak $242.7 \mathrm{~mL}$. Data lebih lengkap mengenai jumlah dan jenis makanan serta minuman yang paling banyak dikonsumsi saat sarapan disajikan pada Tabel 2 berikut.

Hal yang sama juga berlaku jika analisis pangan sarapan favorit/paling banyak dikonsumsi dilakukan berdasarkan status ekonomi rumah tangga anak umur 6-12 tahun. Berdasarkan analisis tersebut diketahui bahwa nasi putih dan air putih tetap menjadi makanan dan minuman yang paling banyak dikonsumsi saat sarapan oleh anak umur 6-12 tahun mulai dari anak yang berasal dari rumah tangga yang ada di kuintil terbawah sampai dengan anak dari rumah tangga dengan kuintil teratas. Data lengkap untuk hasil analisis ini disajikan pada Tabel 3.

\section{Kontribusi Sarapan terhadap Kebutuhan Gizi}

Hasil kajian terhadap data sarapan Riskesdas tahun 2010 menunjukkan $44.6 \%$ anak usia sekolah dasar mengonsumsi sarapan dengan kualitas rendah, yaitu dengan asupan energi sarapan kurang dari 15\% kebutuhan harian (Tabel 5). Persentase anak sekolah yang sarapan dengan kualitas rendah atau dengan kontribusi kandungan zat gizi (protein, vitamin A, besi, kalsium, dan serat) di bawah 15\% berturutturut adalah sebanyak 35.4\%, 67.8\%, 85.0\%, 89.4\%, dan $90.3 \%$. Hal tersebut menunjukkan bahwa permasalahan sarapan pada anak sekolah di Indonesia merupakan permasalahan serius, khususnya jika dikaitkan dengan fungsi sarapan sebagai penyedia zat gizi dalam rangka pencapaian kemampuan akademik yang lebih baik. Hal ini diperkuat dengan hasil penelitian Ahmadi, Sohrabi, dan Eftekhari (2009) serta Akitsuki et al. (2011), yang menunjukkan bahwa karbohidrat dan zat besi memiliki korelasi yang positif dengan kemampuan mengingat jangka pendek pada anak sekolah.

Sebagai pembanding untuk kondisi di Indonesia adalah kondisi di Amerika Latin, bahwa sarapan diartikan kegiatan makan dan minum antara jam 5 sampai jam 9 pagi dan mengandung total energi

Tabel 2. Jumlah Konsumsi dan Partisipasi Konsumsi Sepuluh Jenis Makanan dan Lima Jenis Minuman Sarapan Paling Favorit menurut Jenis Kelamin

\begin{tabular}{|c|c|c|c|c|c|c|}
\hline \multirow{2}{*}{ Pangan } & \multicolumn{2}{|l|}{ Perempuan } & \multicolumn{2}{|l|}{ Laki-laki } & \multicolumn{2}{|l|}{ Total } \\
\hline & Rata-rata \pm SD(median) & $\%$ & Rata-rata $\pm S D$ (median) & $\%$ & Rata-rata \pm SD(median) & $\%$ \\
\hline \multicolumn{7}{|l|}{ Makanan: } \\
\hline Nasi putih (g) & $146.45 \pm 69.37(100)$ & 28.28 & $151.73 \pm 69.73(100)$ & 28.71 & $149.19 \pm 69.61(100)$ & 28.50 \\
\hline Telur ceplok/dadar (g) & $52.07 \pm 18.00(50)$ & 8.47 & $51.77 \pm 18.25(50)$ & 8.24 & $51.91 \pm 18.12(50)$ & 8.35 \\
\hline Tempe goreng (g) & $42.34 \pm 25.61(40)$ & 6.59 & $43.33 \pm 28.26(40)$ & 6.85 & $42.86 \pm 27.04(40)$ & 6.72 \\
\hline Sayur berkuah (g) & $62.67 \pm 44.57(50)$ & 5.82 & $61.99 \pm 43.81(50)$ & 5.73 & $62.32 \pm 44.18(50)$ & 5.78 \\
\hline Ikan goreng (g) & $50.00 \pm 27.75(50)$ & 4.97 & $51.82 \pm 29.93(50)$ & 5.05 & $50.95 \pm 28.91(50)$ & 5.01 \\
\hline Mie Instan (g) & $73.40 \pm 27.82(75)$ & 3.53 & $74.21 \pm 25.37(75)$ & 3.72 & $73.83 \pm 26.55(75)$ & 3.63 \\
\hline Nasi goreng (g) & $163.24 \pm 61.65(150)$ & 3.58 & $156.62 \pm 59.00(200)$ & 3.16 & $164.39 \pm 60.38(200)$ & 3.36 \\
\hline Sayuran (tumis) (g) & $55.91 \pm 47.69(50)$ & 3.31 & $57.94 \pm 50.64(50)$ & 3.35 & $56.96 \pm 49.24(50)$ & 3.33 \\
\hline Tahu goreng (g) & $48.42 \pm 32.97(50)$ & 2.46 & $49.50 \pm 30.67(50)$ & 2.71 & $49.01 \pm 31.75(50)$ & 2.59 \\
\hline Roti, donat, dan turunannya (g) & $61.22 \pm 38.71(50)$ & 2.62 & $62.34 \pm 39.34(50)$ & 2.45 & $61.78 \pm 39.02(50)$ & 2.53 \\
\hline \multicolumn{7}{|l|}{ Minuman: } \\
\hline Air Putih (ml) & $241.35 \pm 82.88(200)$ & 71.68 & $243.93 \pm 84.53(200)$ & 71.12 & $242.67 \pm 83.74(200)$ & 71.39 \\
\hline Teh manis (ml) & $199.16 \pm 37.38(200)$ & 14.21 & $199.22 \pm 38.61(200)$ & 13.97 & $199.19 \pm 38.01(200)$ & 14.09 \\
\hline Susu Kental Manis (g) & $22.84 \pm 5.97(20)$ & 4.27 & $22.71 \pm 6.00(20)$ & 4.36 & $22.77 \pm 5.99(20)$ & 4.32 \\
\hline Susu instan (g) & $28.91 \pm 20.98(30)$ & 4.15 & $26.98 \pm 14.73(27)$ & 4.05 & $27.93 \pm 18.10(27)$ & 4.10 \\
\hline Air teh (g) & $14.16 \pm 52.10(5)$ & 1.77 & $12.64 \pm 43.25(5)$ & 1.85 & $13.36 \pm 47.63(5)$ & 1.81 \\
\hline
\end{tabular}

Tabel 3. Jumlah Konsumsi dan Partisipasi Konsumsi Sepuluh Jenis Makanan dan Lima Jenis Minuman Sarapan Paling Favorit menurut Status Ekonomi Keluarga (Kuintil)

\begin{tabular}{|c|c|c|c|c|c|c|c|c|c|c|}
\hline \multirow{2}{*}{ Pangan } & \multicolumn{2}{|l|}{ Kuintil 1} & \multicolumn{2}{|l|}{ Kuintil 2} & \multicolumn{2}{|l|}{ Kuintil3 } & \multicolumn{2}{|l|}{ Kuintil4 } & \multicolumn{2}{|l|}{ Kuintil5 } \\
\hline & Rata-rata $\pm S D($ Median) & $\%$ & Rata-rata $\pm S D($ Median) & $\%$ & Rata-rata $\pm S D($ Median) & $\%$ & Rata-rata $\pm S D($ Median) & $\%$ & Rata-rata $\pm S D($ Median) & $\%$ \\
\hline \multicolumn{11}{|l|}{ Makanan: } \\
\hline Nasiputih (g) & $148.61 \pm 70.15(100)$ & 31.02 & $149.68 \pm 71.10(100)$ & 29.33 & $148.52 \pm 68.46(100)$ & 28.03 & $149.12 \pm 67.32(100)$ & 26.15 & $150.99 \pm 70.02(100)$ & 25.23 \\
\hline Telur ceplok/dadar (g) & $52.26 \pm 23.84(50)$ & 5.39 & $50.91 \pm 15.22(50)$ & 7.74 & $51.53 \pm 15.31(50)$ & 9.39 & $52.47 \pm 17.26(50)$ & 10.79 & $52.66 \pm 19.03(50)$ & 11.19 \\
\hline Tempe goreng $(\mathrm{g})$ & $43.17 \pm 27.43(40)$ & 8.24 & $43.18 \pm 25.66(40)$ & 7.51 & $42.47 \pm 27.83(40)$ & 6.42 & $42.31 \pm 25.57(40)$ & 5.27 & $42.28 \pm 30.11(30)$ & 4.28 \\
\hline Sayur berkuah (g) & $61.32 \pm 42.79(50)$ & 7.95 & $60.91 \pm 43.79(50)$ & 6.06 & $63.23 \pm 45.46(50)$ & 5.39 & $63.01 \pm 44.30(50)$ & 3.87 & $68.57 \pm 48.36(50)$ & 3.58 \\
\hline Ikan goreng (g) & $46.05 \pm 28.06(50)$ & 4.55 & $49.54 \pm 26.46(50)$ & 5.31 & $53.13 \pm 27.53(50)$ & 5.48 & $55.13 \pm 31.92(50)$ & 5.03 & $54.41 \pm 31.89(50)$ & 4.67 \\
\hline Mie Instan (g) & $72.14 \pm 23.72(75)$ & 2.90 & $73.29 \pm 28.44(75)$ & 3.49 & $74.76 \pm 29.81(75)$ & 3.98 & $73.51 \pm 19.53(75)$ & 4.34 & $76.45 \pm 30.64(75)$ & 3.40 \\
\hline Nasigoreng (g) & $159.93 \pm 61.72(150)$ & 2.51 & $158.10 \pm 59.83(150)$ & 3.11 & $167.89 \pm 61.37(200)$ & 3.61 & $169.50 \pm 60.02(200)$ & 4.17 & $167.40 \pm 57.48(200)$ & 4.22 \\
\hline Sayuran (tumis) (g) & $59.22 \pm 51.58(50)$ & 4.02 & $55.22 \pm 47.20(50)$ & 3.50 & $55.12 \pm 49.74(40)$ & 3.19 & $55.62 \pm 46.04(50)$ & 2.85 & $59.42 \pm 49.60(50)$ & 2.38 \\
\hline Tahu goreng (g) & $48.79 \pm 32.22(50)$ & 2.79 & $48.29 \pm 33.89(50)$ & 2.75 & $49.11 \pm 30.21(50)$ & 2.75 & $47.42 \pm 24.53(50)$ & 2.33 & $54.11 \pm 37.63(50)$ & 1.88 \\
\hline $\begin{array}{l}\text { Roti, donat, dan } \\
\text { turunannya (g) }\end{array}$ & $58.81 \pm 45.83(50)$ & 1.26 & $59.52 \pm 40.98(50)$ & 1.85 & $62.48 \pm 37.70(50)$ & 2.57 & $62.59 \pm 37.35(50)$ & 3.55 & $63.57 \pm 36.12(50)$ & 5.27 \\
\hline \multicolumn{11}{|l|}{ Minuman: } \\
\hline Air Putih (ml) & $238.40 \pm 79.82(200)$ & 78.80 & $240.30 \pm 82.78(200)$ & 74.84 & $243.04 \pm 83.93(200)$ & 70.83 & $246.92 \pm 86.22(200)$ & 66.04 & $250.70 \pm 89.69(200)$ & 60.33 \\
\hline Teh manis (ml) & $199.02 \pm 30.94(200)$ & 13.23 & $198.55 \pm 36.41(200)$ & 14.62 & $200.60 \pm 39.82(200)$ & 14.93 & $198.52 \pm 41.76(200)$ & 14.76 & $199.32 \pm 43.57(200)$ & 12.83 \\
\hline Susu Kental Manis (g) & $21.50 \pm 5.79(20)$ & 1.77 & $22.47 \pm 5.68(20)$ & 3.71 & $23.08 \pm 6.24(20)$ & 5.22 & $23.60 \pm 6.38(20)$ & 6.60 & $22.23 \pm 5.30(20)$ & 5.72 \\
\hline Susu instan (g) & $27.76 \pm 22.56(20)$ & 0.81 & $26.48 \pm 10.29(27)$ & 1.87 & $25.48 \pm 10.19(20)$ & 3.59 & $29.76 \pm 25.49(30)$ & 6.23 & $28.14 \pm 15.41(30)$ & 11.42 \\
\hline Air teh $(\mathrm{g})$ & $14.15 \pm 52.01(5)$ & 2.41 & $12.35 \pm 37.51(5)$ & 1.97 & $9.02 \pm 39.83(5)$ & 1.37 & $21.55 \pm 68.55(5)$ & 1.40 & $9.40 \pm 29.83(5)$ & 1.60 \\
\hline
\end{tabular}


lebih dari $100 \mathrm{kkal}$ (Alexander et al. 2009). Sementara itu Wilson et al. (2006) di New Zealand, dan Smith et al. (2010) di Australia menetapkan waktu sarapan antara jam 6 sampai jam 9 pagi. Sedangkan Barton et al. (2005) dan Affenito et al. (2005) di Amerika menetapkan sarapan jam 5 sampai jam 10 pada hari sekolah dan jam 5 sampai jam 11 pada hari libur hari libur. Batasan sarapan yang terakhir ini tidak tepat karena jam 10 adalah saatnya morning tea atau snack pagi. Sarapan yang baik adalah bila selalu dilakukan pada waktu waktu pagi hari bukan menjelang makan siang, dan tidak perlu dibedakan antara saat hari kerja/sekolah dan hari libur. Batasan sarapan yang akhirnya digunakan adalah batasan sarapan yang dikemukakan oleh Pereira et al. (2011) yaitu makanan yang dikonsumsi di pagi hari (sebelum mulai beraktivitas), paling lambat sampai jam 10 pagi dan memenuhi 20-35\% angka kecukupan energi.

Dari segi jumlah zat gizi sarapan akan menyumbang sekitar seperempat dari asupan zat gizi harian. Hal ini mempertimbangkan bahwa selain dari sarapan asupan zat gizi harian juga diperoleh dari makan siang (lunch), makan malam (dinner) dan snack yang dilakukan diantara waktu makan. Lopez-Sobaler et al. (2003) di Madrid - Spanyol menetapkan sarapan dianggap cukup jika menyediakan minimal 20\% asupan energi harian. Sementara di Amerika latin, sarapan minimal mengandung energi 100 kkal (Alexander et al. 2009). Menurut Khomsan (2005) sarapan sebaiknya menyumbangkan energi sekitar 25\% dari asupan energi harian. Mempertimbangkan hasil kajian kontribusi berbagai zat gizi sarapan terhadap asupan zat gizi harian, seperti disajikan pada Tabel 4 dan 5, maka di Indonesia lebih tepat bila kontribusi zat gizi sarapan adalah 15-30 \% asupan gizi. Oleh karena target asupan gizi harian yang ideal adalah memenuhi kebutuhan gizi (100\% AKG) maka sarapan yang dianjurkan adalah mengandung zat gizi 15-30\% zat gizi, yang dilakukan antara bangun pagi sampai jam 9 pagi.

Berbagai hasil penelitian mengenai sarapan yang dilakukan pada tahun 2002 hingga 2011 di Indonesia menunjukkan kisaran 16.9-59\% anak sekolah di berbagai kota besar tidak sarapan dengan berbagai faktor penyebab. Faktor-faktor yang memengaruhi kebiasaan sarapan menurut Sandercock, Voss dan Dye (2010) serta Ozdogan, Ozcelik, dan Surucuoglu (2010) antara lain: usia anak, jenis kelamin anak, pengetahuan anak mengenai kesehatan dan gizi, ketersediaan makanan pagi di rumah, waktu tempuh atau jarak antara rumah dengan sekolah, jumlah uang saku, kebiasaan jajan yang mengenyangkan, kebiasaan membawa bekal dari rumah, persepsi tubuh ideal (ingin seperti model), serta pendidikan, perkerjaan, dan penghasilan orang tua.

Di Indonesia, menurut (Khomsan 2005) alasan banyaknya anak yang tidak biasa sarapan sebelum berangkat ke sekolah adalah karena tidak tersedia pangan untuk disantap, pangan tidak menarik, jenis pangan yang disediakan monoton (membosankan), tidak cukup waktu (waktu terbatas) karena harus berangkat pagi. Di perkotaan tidak sarapan seringkali disebabkan kesibukan ibu bekerja, dan waktu yang amat terbatas dipagi hari karena harus segera meninggalkan rumah. Bagi orang tua, khususnya ibu, masalah utama untuk membiasakan sarapan pada anak adalah sulitnya membangunkan anak dari tidurnya untuk sarapan (59\%), sulit mengajak anak untuk sarapan (19\%), sulit meminta anak menghabiskan sarapan (10\%), dan kuatir anak telat sekolah (6\%) (Hardinsyah et al. 2012).

Glukosa merupakan sumber energi utama bagi otak. Apabila seseorang melewatkan sarapan

Tabel 4. Kontribusi Energi dan Zat Gizi dari Sarapan Anak Indonesia berdasarkan Jenis Kelamin

\begin{tabular}{lcccccc}
\hline \multirow{2}{*}{ Zat Gizi } & \multicolumn{2}{c}{ Laki-laki } & \multicolumn{2}{c}{ Perempuan } & \multicolumn{2}{c}{ Total } \\
\cline { 2 - 7 } & Rata-rata \pm SD & \% AKG & Rata-rata \pm SD & \% AKG & Rata-rata \pm SD & \% AKG \\
\hline Energi (kkal) & $336 \pm 201$ & 18.11 & $329 \pm 198$ & 17.81 & $333 \pm 200$ & 17.96 \\
Protein (g) & $10.85 \pm 8.55$ & 23.63 & $10.54 \pm 8.21$ & 22.95 & $10.70 \pm 8.38$ & 23.30 \\
Vitamin A (RE) & $85 \pm 161$ & 16.12 & $87 \pm 161$ & 16.45 & $86 \pm 161$ & 16.28 \\
Besi (mg) & $1.21 \pm 1.75$ & 11.16 & $1.24 \pm 2.00$ & 9.92 & $1.23 \pm 1.88$ & 10.56 \\
Kalsium (mg) & $49.91 \pm 69.56$ & 7.20 & $49.95 \pm 71.10$ & 7.20 & $49.93 \pm 70.31$ & 7.20 \\
Serat (g) & $1.33 \pm 1.40$ & 5.33 & $1.31 \pm 1.48$ & 5.26 & $1.31 \pm 1.48$ & 5.30 \\
\hline
\end{tabular}

Tabel 5. Sebaran Subjek menurut Tingkat Kontribusi Asupan Gizi dari Sarapan (\% AKG)

\begin{tabular}{lcccccccc}
\hline \multirow{2}{*}{ Zat Gizi } & \multicolumn{3}{c}{ Laki-lakin(\%) } & \multicolumn{3}{c}{ Perempuann(\%) } \\
\cline { 2 - 8 } & $<5 \%$ AKG & 5-15\% AKG & 16-25\% AKG & $>$ 25\% AKG & $<5 \%$ AKG & 5-15\% AKG & 16-25\% AKG & $>25 \%$ AKG \\
\hline Energi (kkal) & $928(5.1)$ & $6942(38.4)$ & $6597(36.5)$ & $3588(19.9)$ & $979(5.7)$ & $6840(39.9)$ & $6002(35.1)$ & $3303(19.3)$ \\
Proten (g) & $1571(8.7)$ & $4690(26.0)$ & $5150(28.5)$ & $6644(36.8)$ & $1551(9.1)$ & $4624(27.0)$ & $4879(28.5)$ & $6070(35.4)$ \\
Vitamin A(RE) & $6231(34.5)$ & $6007(33.3)$ & $2642(14.6)$ & $3175(17.6)$ & $5760(33.6)$ & $5836(34.1)$ & $2482(14.5)$ & $3046(17.8)$ \\
Besi (mg) & $4376(24.2)$ & $10649(59.0)$ & $2119(11.7)$ & $911(5.0)$ & $6028(35.2)$ & $8825(51.5)$ & $1466(8.6)$ & $805(4.7)$ \\
Kalsium(mg) & $10790(59.8)$ & $5351(29.6)$ & $1054(5.8)$ & $860(4.8)$ & $10233(59.8)$ & $5061(29.6)$ & $993(5.8)$ & $837(4.9)$ \\
Serat (g) & $8005(44.5)$ & $8224(45.7)$ & $1264(7.0)$ & $510(2.8)$ & $7913(46.4)$ & $7509(44.0)$ & $1144(6.7)$ & $495(2.9)$ \\
\hline
\end{tabular}


menyebabkan tubuh kekurangan glukosa atau kadar glukosa di bawah normal (hipoglikemia), pusing, gemetar, lelah dan sulit berkonsentrasi serta memiliki kecenderungan untuk mengalami overweight lebih tinggi karena cenderung mengonsumsi cemilan lebih banyak (Billon et al. 2002; Huang et al. 2010; Pereira et al. 2011; McCrory \& Campbell 2011). Penelitian Faridi (2002) dan Basch (2011) menunjukkan bahwa terdapat hubungan nyata antara kebiasaan sarapan dengan kadar glukosa darah anak usia sekolah, sehingga jika anak tidak sarapan maka dapat mengakibatkan penurunan gairah belajar, kecepatan reaksi, serta kesulitan dalam menerima pelajaran dengan baik yang pada akhirnya akan memberi dampak negatif pada prestasi akademik. Penelitian yang dilakukan oleh Leidy dan Racki (2010) serta Zeng et al. (2011) menyatakan, dengan sarapan pagi lambung akan terisi kembali setelah 8-10 jam kosong sehingga kadar gula dalam darah meningkat lagi serta akan meningkatkan kapasitas tubuh dalam beraktivitas, terutama jika sarapan tersebut tinggi protein.

Selain menyumbangkan glukosa, sarapan juga menyumbangkan zat gizi penting bagi tubuh yang berperan dalam mekanisme daya ingat (kognitif) memori seseorang, meskipun tidak memengaruhi tingkat kecerdasan. Bila terjadi keterlambatan masukan zat gizi (asupan gula ke dalam sel darah) maka dapat menurunkan daya konsentrasi anak sewaktu belajar yang timbul karena lemas, lesu, pusing dan mengantuk. Dampak buruk tidak sarapan yang lain bagi anak antara lain; status gizi (peningkatan IMT), kesehatan dan stamina anak menurun; menggagalkan penanaman kebiasaan gizi seimbang dan pencapaian prestasi optimal anak; pemborosan investasi pendidikan; dan menghambat peningkatan kualitas SDM bangsa (Brown, Beardslee, ProthrowStith 2008; Tin et al. 2011).

Berdasarkan hasil analisis serta bahasan tersebut di atas tampak jelas bahwa masalah tidak sarapan di kalangan penduduk Indonesia masih besar, baik pada anak, remaja maupun dewasa. Selain itu masalah rendahnya asupan gizi dari sarapan juga masalah. Bila hal ini dibiarkan akan turut memengaruhi kemampuan konsentrasi, kemampuan fisik, kejadian kegemukan dan bagi anak sekolah meningkatkan kemungkinan asupan jajanan yang tidak aman. Salah satu upaya yang dapat dilakukan untuk menanamkan kebiasaan sarapan dan pola makan yang baik bagi anak diantaranya adalah dengan promosi dan penerapan dengan suatu program pendidikan yang terpadu (terintegrasi dengan kurikulum pendidikan di sekolah). Hasil penelitian Eilat-Adar et al. (2011) yang dilakukan di Israel menunjukkan bahwa integrasi materi kebiasaan makan dan sarapan yang sehat dalam kurikulum pendidikan terbukti efektif dalam meningkatkan pola makan dan sarapan sehat bagi anak usia sekolah dasar, selain itu juga Bart- feld dan Ahn (2011) menyebutkan bahwa program sarapan sekolah bisa menjadi salah satu strategi efektif dalam membantu ketahanan pangan rumah kelompok ekonomi rendah. Upaya yang dilakukan untuk menjaga kualitas sarapan diantaranya adalah dengan memberikan sarapan bagi anak dalam porsi yang sesuai atau dalam jumlah yang biasa dimakan anak (Carr \& Kranz 2012). Hasil penelitian tersebut menunjukkan bahwa penambahan jumlah dan jenis menu dalam sarapan tidak akan meningkatkan asupan gizi dari sarapan pada anak karena mereka hanya mengonsumsi makanan yang disukai serta dan dalam porsi/jumlah yang mereka makan.

\section{KESIMPULAN}

Sepuluh jenis makanan yang paling favorit dikonsumsi saat sarapan oleh anak 6-12 tahun adalah nasi putih, telur ceplok/dadar, tempe goreng, sayur berkuah, ikan goreng, mie instan, nasi goreng, sayuran (tumis), tahu goreng, serta roti dan turunannya.

Lima jenis minuman yang paling favorit dikonsumsi saat sarapan oleh anak 6-12 tahun adalah air putih, teh manis, susu kental manis, susu instan, dan air teh.

Hampir separuh (44.6\%) anak sarapan dengan mutu gizi rendah. Sekitar 44.6\%, 35.4\%, 67.8\%, $85.0 \%, 89.4 \%$, dan $90.3 \%$ anak hanya mengonsumsi $<15 \%$ kebutuhan gizinya (berturut-turut untuk energi, protein, vitamin A, zat besi, kalsium, dan serat).

Memperhatikan besarnya masalah sarapan, disarankan kepada KEMENKES untuk mengintensifikasikan promosi pesan "biasakan sarapan", sebagai salah satu pesan gizi seimbang secara berkesinambungan.

Sarapan bukan sekedar mengonsumsi pangan di pagi hari, tetapi seharusnya dapat memenuhi 15 $-30 \%$ kebutuhan zat gizi harian. Sementara hasil penelitian menunjukkan anak yang belum memenuhi kebutuhan gizinya saat sarapan sehingga perlu upaya peningkatan pengetahuan dan praktek untuk meningkatkan mutu gizi sarapan.

\section{UCAPAN TERIMA KASIH}

Terima kasih disampaikan kepada Badan Penelitian Pengembangan Kesehatan, Kementerian Kesehatan RI yang telah mengijinkan penulis menggunakan data hasil survei Riskesdas 2010.

\section{DAFTAR PUSTAKA}

Affenito SG, Thompson DR, Barton BA, Franko DL, Daniels SR, Obarzanek E, Schreiber GB, \& Striegel-Moore RH. 2005. Breakfast consump- 
tion by african-american and white adolescent girls correlates positively with calcium and fiber intake and negatively with body mass index. Journal of American Dietetic Association, 2005(105), 938-945.

Ahmadi A, Sohrabi Z, \& Eftekhari MH. 2009. Evaluating the relationship between breakfast pattern and short-term memory in junior high school girls. Pak. J. Biol. Sci., 12(9), 742-745.

Akitsuki Y, Nakawaga S, Sugiura M, \& Kawashima R. 2011. Nutritional quality of breakfast affects cognitive function: An fMRI Study. Neuroscience \& Medicine, 2, 192-197.

Alexander KE, Ventura EE, Spruijt-Metz1 D, Weigensberg MJ, \& Davis JN. 2009. Association of breakfast skipping with visceral fat and insulin indices in overweight latino youth. Nature publishing group, 1528-1533. doi:10.1038/ oby.2009.127.

Bartfeld JS \& Ahn HM. 2011. The school breakfast program strengthens household food security among low-income households with elementary school children, J. Nutr. 141, 470-475.

Barton BA, Eldridge AL, Thompson D, Affenito SG, striegel-moore $\mathrm{RH}$, Franko DL, Albertson AM, \& Crockett SJ. 2005. The relationship of breakfast and cereal consumption to nutrient intake and Body Mass Index: The National Heart, Lung, and Blood Institute Growth and Health Study. Journal of American Dietetic Association, 2005(105),1383-1389.

Basch CE. 2011. Breakfast and the achievement gap among urban minority youth. J Sch Health, 81, 635-640.

Billon S, Lluch A, Gueguen R et al. 2002 Family resemblance in breakfast energy intake: the Stanislas Family Study. European Journal of Clinical Nutrition 56, 1011-9.

Brown JL, WH Beardslee, Deborah Prothrow-Stith. 2008. Impact of scholl breakfast on children's health and learning: an analysis of the scientific research. Harvard School of Public Health, Sodexo Foundation.

Carr N \& Kranz S. 2012. A pilot study on the new USDA meal pattern for school breakfast in a sample of first-grade students. Food and Nutrition Sciences, 3, 1329-1333.

Eilat-Adar S, Koren-Morag N, Siman-Tov M, Livne I, \& Altmen H. 2011. School-based intervention to promote eating daily and healthy breakfast: A survey and a case-control study. European Journal of Clinical Nutrition, 65, 203-209.

Faridi A. 2002. Hubungan sarapan pagi dengan kadar glukosa darah dan konsentrasi belajar pada siswa sekolah dasar [skripsi]. Bogor: Fakultas Pertanian, Institut Pertanian Bogor.

Gibson SA \& Gunn P. 2011. What's for breakfast? Nutritional implications of breakfast habits: insights from the NDNS dietary records. Nutrition Bulletin, 36, 78-86.

Hardinsyah, Khomsan A, Briawan D, \& Aries M. 2012. Start Your Day with Nutritious Whole Grain Breakfast. Jakarta.

Hardinsyah. 2012. Masalah dan Pentingnya Sarapan bagi Anak. Materi Simposium Sarapan Sehat tanggal 16 Juni 2012. Jakarta.

Huang CJ, Hu HT, Fan YC1, Liao YM, \& Tsai PS. 2010. Associations of breakfast skipping with obesity and health-related quality of life: evidence from a national survey in Taiwan. International Journal of Obesity, 34, 720-725.

INPRES Nomor 1 tahun 2010 tanggal 19 Februari 2010. Tentang Percepatan Pelaksanaan Prioritas Pembangunan Nasional tahun 2010, Presiden RI.

INPRES Nomor 1 Tahun 1997 tanggal 15 Januari 1997. Program Makanan Tambahan Makanan Sekolah, Presiden RI.

Khomsan A. 2005. Pangan dan Gizi untuk Kesehatan 2. Bogor: Departemen Gizi Masyarakat, Fakultas Ekologi Manusia, Institut Pertanian Bogor.

Kral TVE, Whiteford LM, Heo M, \& Faith MS. 2011. Effects of eating breakfast compared with skipping breakfast on ratings of appetite and intake at subsequent meals in 8- to 10-y-old children. Am J Clin Nutr, 2011;93, 284-91.

Leidy HJ \& Racki EM. 2010. The addition of a protein-rich breakfast and its effects on acute appetite control and food intake in 'breakfast-skipping' adolescents. International Journal of Obesity (2010) 34, 1125-1133; doi:10.1038/ijo.2010.3.

Lopez-Sobaler AM, Ortega RM, Quintas ME, Navia B, \& Requejo AM. 2003. Relationship between habitual breakfast and intellectual performance (logical reasoning) in well-nourished schoolchildren of Madrid (Spain). European Journal of Clinical Nutrition, 57(Suppl 1), S49-S53.

McCrory MA \& Campbell WW. 2011. Effects of eating frequency, snacking, and breakfast skipping on energy regulation: Symposium overview, J. Nutr, 141, 144-7.

Morales F, Vilas MVA, Vega CJM, Para MCM. 2011. Breakfast quality and its relationship to the prevalence of overweight and obesity in adolescents in Guadalajara (Spain). Nutr Hosp, 26(S), 9S2-958.

Pereira MA, Erickson E, McKee P, Schrankler K, Raatz S, Lytle LA, Pellegrini A. 2011. Breakfast frequency and quality may affect glycemia and appetite in adults and children. J Nutr, 141, 163-8.

Ozdogan Y, Ozcelik AO, \& Surucuoglu MS. 2010. The breakfast habit of female university students. Pakistan Journal of Nutrition, 9(9), 882-886.

Sandercock GR, Voss C, \& Dye L. 2010. Associations 
between habitual schoolday breakfast consumption, body mass index, physical activity and cardiorespiratory fitness in English school children. European Journal of Clinical Nutrition 64(10), 1086-92.

Schusdziarra V, Hausmann M, Wittke C, Mittermeier J, Kellner M, Naumann A, Wagenpfeil S, \& Erdmann J. 2011. Impact of breakfast on daily energy intake-an analysis of absolute versus relative breakfast calories. Nutrition Journal, $10,5$.

Simon DT, Grantham-McGregor S. 1989. Effects of missing breakfast on the cognitive functions of school children of differing nutritional status. American Journal Clinical Nutrition 1989 (49), 646-53.

Smith KJ, Gall SL, McNaughton SA, Blizzard L, Dwyer T, \& Venn AJ. 2010. Skipping breakfast: lo- ngitudinal associations with cardiometabolic risk factors in the Childhood Determinants of Adult Health Study. American Journal of Clinical Nutrition, 92, 1316-25.

Tin SPP, Ho SY, Mak KH, Wan KL, \& Lam TH. 2011. Breakfast skipping and change in body mass index in young children. International Journal of Obesity, 35, 899-906; doi:10.1038/ ijo.2011.58

Wilson NC, Parnell WR, Wohlers M, \& Shirley M. 2006. Eating breakfast and its impact on children's daily diet. Nutrition \& Dietetics, 63, 15-20

Zeng YC, Li SM, Xiong GL, Su HM, \& Wan JC. 2011. Influences of protein to energy ratios in breakfast on mood, alertness and attention in the healthy undergraduate students. HEALTH, 3, 383-393. 